\title{
Pengaruh Produksi Dan Konsumsi Terhadap Impor Komoditi Beras Di Provinsi Jambi
}

\author{
Heppi Syofya \\ STIE Sakti Alam Kerinci \\ e-mail : hsyofya@gmail.com
}

\begin{abstract}
Rice is a strategic commodity as food for the people of Indonesia, so that the production, supply, procurement and distribution of rice becomes very important in the framework of food security, increasing income and welfare of farmers, in order to stabilize the interest of public consumption in general, import of rice is not always indicated because the inability of the region to produce rice but it is necessary to maintain the availability of rice in order to avoid a deficit that will affect the price increase, given the function of rice as staple food, rice sales will be continuous, meaning that sales will continue throughout the year so that the business prospect is considered sufficient promising for years to come. In farm processing, farmers seek to obtain economically profitable, where the cost incurred can produce maximum production. To support the availability of rice food, the procurement of rice's, especially from regional sources. The procurement of rice in Jambi province, in addition to the procurement of rice in the region, also comes from the national move and rice stock from the previous year.
\end{abstract}

\section{Keyword's : primer sectors, rice commodity}

\section{PENDAHULUAN}

Kehidupan manusia tidak terlepas dari kebutuhan akan pangan, maka urusan pangan menjadi suatu kebutuhan yang vital bagi manusia. Pangan adalah segala sesuatu yang berasal dari sumber hayati dan air, baik diolah maupun tidak diolah, yang diperuntukan sebagai makanan atau minuman bagi konsumsi manusia, termasuk bahan tambahan pangan, bahan baku pangan, dan bahan lain yang digunakan dalam proses penyiapan, pengolahan, dan/atau pembuatan makanan atau minuman (BKP-Departemen Pertanian, 2008 : 72). FAO (2008) dalam Suryana (2008: 61) menyatakan bahwa, pangan merupakan kebutuhan dasar manusia (HAM), pemerintah wajib menyediakan pangan yang layak. Hal ini tertuang dalam Deklarasi Roma tahun 1996 pada KTT Pangan Dunia dan Deklarasi Millenium (MDGs) tahun 2000 yang menyepakati penurunan jumlah penduduk lapar hingga setengahnya pada tahun 2015 dan International Convenant on Economic, Social and Cultural Rights (ICOSOC) yang diratifikasi dengan Undang-Undang Nomor 11 Tahun 2005 yang berisi tentang; 1). Hak setiap orang atas standar kehidupan yang layak baginya dan keluarganya atas pangan. 2). Setiap orang harus bebas dari kelaparan. Pangan merupakan kebutuhan pokok yang harus dipenuhi demi keberlangsungan hidup manusia. Jika terjadi kelangkaan dalam kebutuhan vital ini maka keseimbangan dalam kehidupan manusia juga akan terganggu. Direktorat Jenderal Pajak (2012 : 166) impor beras merupakan salah satu impor barang yang dikenakan pajak tertentu yang bersifat strategis yang dibebaskan 
pajak pertambahan nilai (PPN). Selain itu dalam prosedur pemberian fasilitas impor beras atau barang hasil pertanian tidak menggunakan surat keterangan bebas pajak pertambahan nilai (SKB PPN), hanya barang modal yang menggunakan SKB PPN. Tujuan dari pembebasan PPN adalah untuk menjamin tersedianya barang-barang yang bersifat strategis tersebut (Direktorat Jenderal Pajak, 2012 : 167).

Menurut Rosner (2008 : 44)

konsumsi beras lebih besar dari produksi beras, menunjukkan bahwa masyarakat Indonesia mayoritas makanan pokonya adalah beras. Untuk memenuhi kebutuhan konsumsi masyarakat Indonesia, pemerintah melakukan impor beras. Semua negara di dunia memandang penting ketahan pangan dan gizi, begitupun negara Indonesia. Pemerintah Indonesia yang terdiri dari presiden, gubernur, bupati/walikota pada berbagai dokumen pembangunan nasional menyatakan bahwa ketahanan pangan sebagai salah satu prioritas pembangunan. Karena membangun ketahanan pangan merupakan hal yang seharusnya dilakukan oleh suatu negara, pembangunan ketahanan pangan memerlukan cakupan luas, keterlibatan lintas sektor, multidisiplin, dan penekanan pada basis sumberdaya lokal (impor pangan; the last resort). Adapun operasionalisasi ketahanan pangan pada berbagai tingkat pemerintahan di Indonesia yaitu pada tingkat nasional dilakukannya swasembada pada komoditas strategis, pada tingkat provinsi, kabupaten/kota dan desa dengan melakukan pemanfaatan potensi lokal dan pada tingkat masyarakat dilakukannya peningkatan kemampuan fisik, sosial, politik dan ekonomi (BKPDepartemen Pertanian, 2008 : 78).
Dibandingkan dengan konsumsi pangan beras di negara-negara Asia khususnya Jepang, Indonesia jauh lebih tinggi dimana rata-rata konsumsi beras di Jepang hanya sekitar $60 \mathrm{~kg} / \mathrm{kapita} /$ tahun (Sutrisno dan Rudi Wibowo, 2005 : 28). Untuk Provinsi Jambi, walaupun belum ada penelitian khusus untuk itu, diperkirakan konsumsi beras 135 kg/kapita/tahun. Dengan pertambahan penduduk Provinsi Jambi sekitar $2 \%$ per tahun, sementara laju pertumbuhan produktivitas menurun, maka analisis terhadap ketersediaan beras perlu dilakukan karena selain konsumsi untuk rumah tangga, beras juga digunakan sebagai bahan baku industri terutama untuk tepung beras, bihun dan industri makanan lainnya. Sektor pertanian di Provinsi Jambi sekarang ini masih tetap merupakan sektor pertumbuhan ekonomi Daerah Jambi. Keadaan ini tercermin dari besarnya sumbangan sektor pertanian terhadap pembentukan PDRB Provinsi Jambi. Mengingat fungsi beras sebagai makanan pokok, penjualan beras pun akan berlangsung kontinyu, artinya penjualan akan terus berlangsung sepanjang tahun. Sehingga prospek usaha ini dirasa cukup menjanjikan untuk tahun-tahun ke depan. Dalam pengolahan usahatani, petani mengupayakan agar hal yang diperoleh secara ekonomis menguntungkan, di mana biaya yang dikeluarkan dapat menghasilkan produksi maksimal. Untuk mendukung ketersediaan pangan beras tersebut produksi pengadaan beras terutama dari sumber-sumber daerah. Pengadaan beras di Provinsi Jambi selain berasal dari pengadaan beras dalam daerah, juga berasal luar daerah (move nasional) serta stok (persediaan) beras dari tahun sebelumnya. Adapun tujuan 
pengadaan beras dari luar daerah (move nasional) adalah untuk menjamin ketersediaan beras apabila pengadaan beras dari dalam daerah Provinsi Jambi tidak mampu untuk memenuhi kebutuhan konsumsi. Impor beras tidak selalu diindikasikan karena ketidakmampuan daerah dalam memproduksi beras tapi diperlukan untuk menjaga ketersediaan beras agar tidak terjadi defisit yang akan berdampak kepada kenaikan harga. Tujuan penelitian ini adalah untuk mengetahui adanya pengaruh, besarnya pengaruh produksi dan konsumsi terhadap impor komoditi beras di Provinsi Jambi selama 10 tahun terakhir.

\section{STUDI PUSTAKA}

Direktorat Jenderal Pajak (2012:166) impor beras merupakan salah satu impor barang yang dikenakan pajak tertentu yang bersifat strategis yang dibebaskan pajak pertambahan nilai (PPN). Selain itu dalam prosedur pemberian fasilitas impor beras atau barang hasil pertanian tidak menggunakan surat keterangan bebas pajak pertambahan nilai (SKB PPN), hanya barang modal yang menggunakan SKB PPN. Tujuan dari pembebasan PPN adalah untuk menjamin tersedianya barang-barang yang bersifat strategis tersebut (Direktorat Jenderal Pajak, 2012:167). Beras merupakan komoditi strategis sebagai bahan pangan bagi masyarakat Indonesia, sehingga kegiatan produksi, penyediaan, pengadaan dan distribusi beras menjadi sangat penting dalam rangka ketahanan pangan, peningkatan pendapatan dan kesejahteraan petani, dalam rangka stabilitas kepentingan konsumsi masyarakat secara umum. Menperindag memandang perlu mengatur ketentuan tersebut melalui
Surat Keputusan Menperindag Nomor 9/MPP/Kep/1/2004, tentang Ketentuan Impor Beras, antara lain : 1). Perusahaan yang melakukan impor harus memiliki Angka Pengenal Importir (API), 2). Beras hanya dapat diimpor oleh importir yang telah mendapat pengakuan sebagai Importir Produsen Beras (IP Beras) dan oleh importir yang telah mendapat penunjukan sebagai Importir Terdaftar Beras (IT Beras), 3). Impor beras dilarang dalam masa 1 (satu) bulan sebelum panen raya, selama panen raya dan 2 (dua) bulan setelah panen raya, 4). Beras yang diimpor oleh IP Beras hanya boleh dipergunakan sebagai bahan baku untuk proses produksi industri yang dimilikinya dan dilarang diperjual belikan maupun dipindahtangankan, dan 5). Setiap kali importasi beras oleh IT Beras harus mendapat persetujuan impor terlebih dahulu dari Direktur Jenderal Bina Pengolahan dan Pemasaran Hasil Pertanian (BPPHP), mengenai jumlah dan jenis beras, pelabuhan tujuan dan waktu pengimporan. Pelaksanaan setiap importasi beras oleh IP Beras atau IT Beras wajib terlebih dahulu dilakukan verifikasi atau penelusuran teknis di negara muat barang. Menurut Rita dalam Yoga (2013:84) impor ditentukan oleh kesanggupan atau kemampuan dalam meghasilkan barang-barang yang bersaing dengan barang luar negeri. Hal ini berarti nilai impor bergantung pada tingkat nilai pendapatan nasional suatu negara. Semakin tinggi tingkat pendapatan nasional dan semakin rendah kemampuan negara tersebut dalam menghasilkan barang-barang tertentu, maka kegiatan impor pun akan semakin tinggi. Menurut Atmadji dalam Yulianti (2012:67) alasan suatu negara melakukan impor disebabkan adanya kegagalan negara 
tersebut dalam memenuhi kebutuhan dalam negeri, baik dalam bentuk kualitas maupun kuantitas. Ketidakmampuan suatu negara dalam menyediakan kebutuhan beras terjadi akibat negara tersebut tidak dapat berproduksi secara efisien. Jumlah impor terus meningkat bukan berarti dapat mencukupi kebutuhan beras di dalam negeri. Sebab jumlah penduduk Indonesia tiap tahun meningkat sehingga peningkatan jumlah impor beras dimaksudkan untuk mengimbangi peningkatan jumlah penduduk yang mengkonsumsi beras. Menurt Thomas et al (2013:41) ada banyak faktor yang mempengaruhi impor beras di Indonesia, yaitu : Harga beras, cadangan devisa, jumlah penduduk, produksi beras, tingkat konsumsi beras, produk domestik bruto (PDB), pendapatan perkapita, kurs rupiah, stok beras dan tingkat inflasi.

Konsumsi merupakan sejumlah barang yang digunakan langsung oleh masyarakat untuk memenuhi kebutuhannya. Keynes menyatakan bahwa konsumsi sangat bergantung pada pendapatan sekarang. Karena itu para ekonom terbaru menyatakan bahwa konsumen memahami kalau mereka menghadapi keputusan antar waktu. Konsumen menatap sumberdaya dan kebutuhan masa depan mereka, yang menunjukan fungsi konsumsi yang lebih komleks dibanding fungsi konsumsi yang Keynes berikan. Keynes menyatakan bentuk fungsi konsumsi : Konsumsi $=\mathrm{f}$ (pendapatan sekarang) Sedangkan studi terbaru menyatakan : Konsumsi = $\mathrm{f}$ (pendapatan sekarang, kekayaan, pendapatan masa depan yang diharapkan, tingkat bunga) Dengan kata lain pendapatan sekarang hanya merupakan salah satu determinan dari konsumsi agregat (Mankiw, 2003:118). Kebutuhan terhadap bahan pangan merupakan salah satu diantara barangbarang primer. Bagi penduduk Indonesia, beras merupakan bahan makanan yang lebih superior daripada bahan pangan lainnya seperti jagung, ubi, sagu dan lainnya. Sehingga bagi masyarakat yang berpendapatan rendah akan berupaya semaksimal mungkin untuk memenuhi kebutuhan pangan pokoknya, terutama pangan beras. Oleh karena itu, konsumsi pangan sangat terkait erat dengan tingkat kesejahteraan masyarakat (Irawan, 2009:66). Kesejahteraan dapat dikatakan makin baik apabila kalori dan protein yang dikonsumsi penduduk semakin meningkat, sampai akhirnya melewati standar kecukupan konsumsi per kapita sehari. Malian et.all (2004:73) konsumsi beras dipengaruhi oleh jumlah penduduk, harga beras di pasar domestik, impor beras tahun sebelumnya, harga jagung pipilan di pasar domestik dan nilai tukar riil. Tambahan penduduk dan melonjaknya konsumsi beras di negara-negara Afrika. Naiknya permintaan beras dari negara-negara itu menambah semakin meningkatnya pasar beras dunia. Permintaan beras makin tinggi, padahal volume beras yang di perdagangkan di pasar dunia merosot. Belum lagi dampak perubahan iklim global yang menyebabkan terjadinya perubahan musim hujan dan kemarau yang ekstrem di sejumlah negara pengekspor beras seperti Thailand, Vietnam, Pakistan, India dan China mendorong negara-negara itu lebih mementingkan stok beras untuk warganya. Hingga saat ini masih ada komitmen yang kuat, terutama dari pemerintah, untuk mempertahankan swasembada beras nasional pada masa mendatang. Produksi pertanian tidak terlepas dari pengaruh kondisi 
alam setempat yang merupakan salah satu faktor pendukung produksi. Selain keadaan tanah yang cocok untuk kondisi tanaman tertentu, iklim juga sangat menentukan. Seperti halnya tanaman pertanian padi. Hanya pada kondisi tanah dan iklim tertentu dapat tumbuh dan berproduksi dengan baik. Keadaan tanah dapat diatasi dengan penggunaan pupuk. Oleh karena itu salah satu faktor produksi padi adalah harga pupuk, selain dari harga output padi sendiri. Iklim yang mendukung dengan curah hujan yang tinggi sangat mempengaruhi pertumbuhan padi, karena tanaman padi terkait dengan ketersediaan air. Jika curah hujan tinggi, maka ketersediaan air juga akan meningkat. Akan tetapi perlu adanya faktor pendukung lain diantara dibangunnya sarana dan prasarana pertanian (Soekartawi, 2002:68). Besar kecilnya produksi beras akan berpengaruh terhadap kontribusi sektor pertanian terhadap PDB. Jika PDB Indonesia meningkat maka pertumbuhan ekonomi juga akan meningkat. Untuk mengimbangi dan mengatasi kebutuhan pangan yang terus meningkat ini, petani harus meningkatkan produksi beras karena sebenarnya meskipun sebagai bahan makanan pokok beras dapat diganti atau disubstitusi oleh bahan makanan lainnya, namun beras memiliki nilai tersendiri bagi orang yang biasa makan nasi dan tidak dapat dengan mudah digantikan oleh bahan makanan yang lain (Soekartawi, 2002:70). Fungsi produksi merupakan hubungan kuantitatif antara masukan dan produksi. Masukan seperti pupuk, tanah, tenaga kerja, modal, dan iklim yang mempengaruhi besar kecilnya produksi yang diperoleh. Jika bentuk fungsi produksi diketahui, maka informasi harga dan biaya yang dikorbankan dapat dimanfaatkan untuk menentukan kombinasi masukan yang baik.

\section{METODE}

Data yang digunakan dalam penelitian ini adalah data sekunder tahun 2009 sampai dengan data tahun 2015, yaitu data yang diperoleh dari Badan Pusat Statistik (BPS) Provinsi Jambi, Dinas Pertanian dan Tanaman Pangan Provinsi Jambi serta sumber data lainnya yang mendukung. Untuk mengetahui pengaruh produksi dan konsumsi terhadap impor komoditi beras di Provinsi Jambi

$\mathrm{Y}=\mathrm{a}+\beta 1 \mathrm{X} 1+\beta 2 \mathrm{X} 2+\mathrm{e}$

Dimana : $\mathrm{Y}$ : Impor Beras; $\mathrm{X} 1$ :

Produksi Beras; $\mathrm{X} 2$ : Konsumsi

Beras; e : error; a : konstanta;

dan $\beta$ : Koefisien regresi

Analisis

koefisien

determinasi digunakan untuk melihat berapa besar pengaruh variabel $\mathrm{X}$ terhadap variabel $\mathrm{Y}$

$\mathrm{KD}=\mathrm{r}^{2} \times 100 \%$

Dimana : KD :

Koefisien

Determinasi; dan $r$ : Korelasi

\section{HASIL}

Berdasarkan Tabel 1 berikut diketahui nilai $F$ hitung sebesar 11,952 sedangkan $\mathrm{F}$ tabel $(\alpha=0.05$; $\mathrm{db}$ regresi $=2: \mathrm{db}$ residual $=4$ ) adalah sebesar 6,94 hal ini berarti H0 ditolak dan $\mathrm{Ha}$ diterima sehingga dapat disimpulkan bahwa impor komoditi beras pada tahun 2009 sampai dengan tahun 2015 dapat dipengaruhi secara signifikan oleh variabel bebas yaitu variabel produksi dan konsumsi beras. Sedangkan pada table 2 berikut didapatkan koefisien determinasi $\mathrm{R}^{2}$ sebesar 0,822 artinya $82,2 \%$ variabel impor beras dapat dijelaskan oleh variabel bebasnya, yaitu produksi dan konsumsi beras, sisanya $17,8 \%$ dijelaskan oleh variabel lain yang 
tidak diteliti dalam penelitian ini. Selain koefisien determinasi, juga didapat koefisien korelasi yang menunjukkan besarnya hubungan antara variabel bebas yaitu impor beras dengan variabel produksi dan konsumsi beras, nilai $\mathrm{R}$ (koefisien korelasi) sebesar 86,8 nilai korelasi ini menunjukkan bahwa hubungan antara variabel produksi dan konsumsi beras dengan variabel impor komoditi beras termasuk kategori "Sangat Kuat" karena berada pada selang 0,80-1,000.

Tabel 1

Anova

\begin{tabular}{|l|l|r|r|r|r|r|}
\hline \multicolumn{2}{|l|}{ Model } & Sum of Squares & df & Mean Square & F & Sig. \\
\hline 1 & Regression & 1895005187,213 & 2 & 947502593,607 & 11,952 &, $009^{\mathrm{b}}$ \\
& Residual & 3981321216,501 & 4 & 995330304,125 & & \\
& Total & 5876326403,714 & 6 & & & \\
\hline
\end{tabular}

Sumber : Data diolah

Tabel 2

Model Summary ${ }^{b}$

\begin{tabular}{|c|c|r|r|r|r|}
\hline Model & R & R Square & Adjusted R Square & Std. Error of the Estimate & Durbin-Watson \\
\hline 1 &, $868^{\mathrm{a}}$ &, 822 &, 716 & 31548,85583 & 1,237 \\
\hline
\end{tabular}

Sumber : Data diolah

Tabel 3

Coefficients $^{\mathrm{a}}$

\begin{tabular}{|l|l|r|r|r|r|r|}
\hline \multicolumn{2}{|c|}{ Model } & \multicolumn{1}{|c|}{ Unstandardized Coefficients } & Standardized Coefficients & \multirow{2}{*}{ t } & \multirow{2}{*}{ Sig. } \\
\cline { 3 - 7 } & \multicolumn{1}{|c|}{ B } & Std. Error & & & \\
\hline 1 & $($ Constant $)$ & $-461886,699$ & 455753,637 & & $-1,013$ &, 013 \\
& $X_{1}$ & $-2,940$ &, 779 &, 552 & $-3,206$ &, 002 \\
& $X_{2}$ & 3,024 &, 316 &, 035 & 3,076 &, 004 \\
\hline
\end{tabular}

Sumber : Data diolah

Diperoleh nilai t-hitung untuk produksi besar sebesar 3,206 dan ttabel $(\alpha=0.05 ; \mathrm{db}$ residual $=4)$ adalah sebesar $-2,132$, t-hitung $<\mathrm{t}$ tabel yaitu $-3,206<-2,132$ berarti dapat disimpulkan bahwa terdapat pengaruh yang signifikan antara variabel produksi beras dengan impor komoditi beras dan dapat dibuktikan dengan nilai signifikansi 0,002 , sedangkan dalam pengujian menggunakan alpha sebesar 0,05 hal ini berarti nilai signifikansi $0,002<$ 0,05 maka pengaruh produksi beras adalah signifikan. Hal ini berarti $\mathrm{H} 0$ ditolak dan Ha diterima atau dengan kata lain bahwa produksi beras merupakan faktor yang dapat menurunkan impor komoditi beras secara nyata. Diperoleh nilai t-hitung konsumsi beras sebesar 3,076 dan ttabel $(\alpha=0.05 ; \mathrm{db}$ residual $=4)$ adalah sebesar 2,132, $\mathrm{t}$ hitung $>\mathrm{t}$ tabel yaitu 3,076> 2,132 atau nilai signifikansi 0,004 , sedangkan dalam pengujian menggunakan alpha sebesar 0,05 hal ini berarti nilai signifikansi $0,004<0,05$ maka terdapat pengaruh yang signifikan antara konsumsi beras terhadap impor komoditi beras. Hal ini berarti HO ditolak dan Ha diterima, sehingga dapat disimpulkan bahwa impor komoditi beras dapat dipengaruhi secara signifikan oleh variabel konsumsi beras atau dengan kata lain bahwa konsumsi beras merupakan faktor yang dapat meningkatkan 
impor komoditi beras secara nyata, diperoleh persamaan regresi dan besarnya pengaruh nilai variabel $\mathrm{X} 1$, $\mathrm{X} 2$ dan Y sebagai berikut :

$\mathrm{Y}=-461886,699-2,940 \mathrm{X} 1+3,024$ $\mathrm{X} 2$

Besarnya kontribusi variabel bebas terhadap variabel terikat, antara lain produksi beras sebesar 2,940 dan konsumsi beras sebesar 3,024 sehingga dapat disimpulkan bahwa produksi beras berpengaruh negatif terhadap impor komoditi beras atau apabila produksi beras meningkat, maka akan diikuti penurunan impor komoditi beras sedangkan konsumsi beras berpengaruh positif terhadap impor komoditi beras atau apabila konsumsi beras meningkat, maka akan diikuti peningkatan impor komoditi beras.

\section{SIMPULAN}

Terdapat pengaruh yang signifikan antara variabel produksi dan konsumsi beras terhadap impor komoditi beras di Provinsi Jambi pada tahun 2009-2015, besarnya pengaruh produksi dan konsumsi beras terhadap impor komoditi beras di Provinsi Jambi secara serentak adalah sebesar 82,2\%, sedangkan sisanya $17,8 \%$ dijelaskan oleh variabel lain yang tidak diteliti dalam penelitian ini, terdapat pengaruh yang signifikan antara variabel produksi beras terhadap impor komoditi beras di Provinsi Jambi, besarnya pengaruh variabel produksi beras terhadap impor komoditi beras di Provinsi Jambi adalah dengan nilai $\beta 1=-2,940$, artinya jika produksi beras meningkat sebesar 1 ton maka impor beras akan menurun sebesar 2,940 dengan asumsi variabel yang lainnya konstan, terdapat pengaruh yang signifikan antara variabel konsumsi beras terhadap impor komoditi beras di Provinsi Jambi dan besarnya pengaruh variabel konsumsi beras terhadap impor beras di Provinsi Jambi adalah dengan nilai $\beta 1=3,024$, artinya jika konsumsi beras meningkat sebesar 1 ton maka impor beras akan meningkat sebesar 3,024 dengan asumsi variabel yang lainnya konstan.

\section{DAFTAR PUSTAKA}

Badan Pusat Statistik Provinsi (BPS) Provinsi Jambi. Jambi Dalam Angka. 2016.

Dinas Pertanian dan Perkebunan Provinsi Jambi. 2016.

Petunjuk Pelaksanaan

Program Peningkatan

Produksi Padi Menuju

Swasembada Beras Tahun

2020. Tahun Anggaran 2016.

Departemen Pertanian. 2008. Data

Based Komoditas Padi.

Jakarta : Departemen

Pertanian Republik

Indonesia.

Irawan, Andi. 2009. Integrasi Pasar

Beras Indonesia. Dalam

Jurnal. Jakarta : Institute For

Science and Technology

Studies (ISTECS).

Malian et. all. 2004. Analisis Dampak Kebijakan Harga Dasar Padi dan Subsidi

Pupuk terhadap Permintaan

dan Penawaran Beras di

Indonesia. Institut Pertanian Bogor, Bogor.

Mankiw, N.G. 2003. Teori Makroekonomi. Edisi kelima. Terjemahan. Jakarta Erlangga.

Rosner, L. Peter Neil McCulloch. 2008. A Note On Rice Production, Consumion and Import Data In Indonesia. Bulletin of Indonesian Economic Studies. 44(1) March 81-92

Soekartawi. 2002. Prinsip-prinsip Dasar Ekonomi Pertanian, Teori dan Aplikasinya. 
Fakultas Pertanian Brawijaya : Malang.

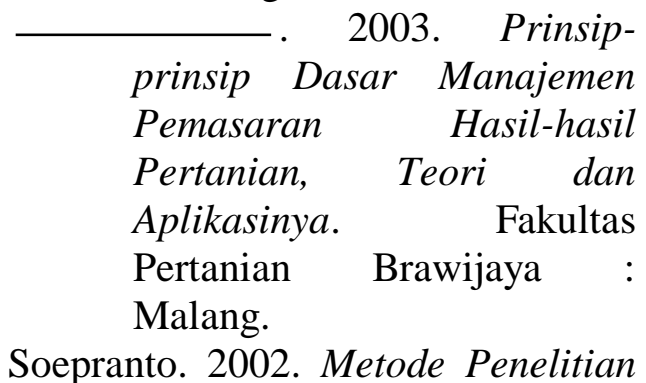

Soepranto. 2002. Metode Penelitian Suatu Pendekatan Proposal. Bumi Aksara, Jakarta.

Sutrisno dan Rudi Wibowo. 2005. Efektifitas Diversifikasi Konsumsi Pangan Rumah Tangga Miskin Pedesaan dalam Rangka Mewujudkan Ketahanan Pangan. Disertasi, Program Pascasarjana Universitas Brawijaya, Malang.

Thomas, Rachel. Wan Nadiah, W. A. and Rajeev Bhat. 2013. Physiochemical properties, proximate composition, and imported rice varieties marketed in Penang Malaysia. International Food Research Journal. 20(3) march Food Technology Division, School of Industrial Technology, Universiti Sains Malaysia.

Yoga, Aditya Bangga. 2013. Pengaruh jumlah Produksi Kedelai Dalam Negeri, Harga Kedelai Dalam Negeri dan Kurs Dollar Amerika Terhadap Volume Impor Kedelai Indonesia. E-Jurnal EP Unud. 2(3) Maret. Fakultas Ekonomi dan Bisnis Universitas Udayana. 